\title{
Selectivity and efficiency of herbicides in weed control on sweet sorghum ${ }^{1}$
}

\author{
Leandro Galon ${ }^{2}$, Franciele Fátima Fernandes ${ }^{2}$, \\ André Andres ${ }^{3}$, Alexandre Ferreira da Silva ${ }^{4}$, César Tiago Forte ${ }^{2}$
}

\section{ABSTRACT}

The lack of registered herbicides for weed control in sweet sorghum has been a limiting production factor. This study aimed at evaluating the selectivity of herbicides in sweet sorghum and weed control efficiency. A randomized blocks design, with four replications, was used. Treatments consisted of sweet sorghum cultivars (BRS 506, BRS 509 and BRS 511) and herbicides applied alone at preemergence (atrazine - 1,500 $\mathrm{g} \mathrm{ha}^{-1}$; atrazine $+\mathrm{s}$-metolachlor $1,665 \mathrm{~g} \mathrm{ha}^{-1}+1,035 \mathrm{~g} \mathrm{ha}^{-1}$; flumioxazin - $50 \mathrm{~g} \mathrm{ha}^{-1}$; s-metolachlor $1,440 \mathrm{~g} \mathrm{ha}^{-1}$ ) and post-emergence (tembotrione - $100.8 \mathrm{~g} \mathrm{ha}^{-1}$ ) and sequentially at pre- and post-emergence (atrazine + s-metolachlor + tembotrione - 1,665 $\mathrm{g} \mathrm{ha}^{-1}+1,035 \mathrm{~g} \mathrm{ha}^{-1}+$ $100.8 \mathrm{~g} \mathrm{ha}^{-1}$; atrazine + tembotrione $-1,500 \mathrm{~g} \mathrm{ha}^{-1}+100.8 \mathrm{~g} \mathrm{ha}^{-1}$; flumioxazin + tembotrione $\left.-50 \mathrm{~g} \mathrm{ha}^{-1}+100.8 \mathrm{~g} \mathrm{ha}^{-1}\right)$, plus two controls, one weeded and one unweeded. The phytotoxicity rate to sorghum was $98.0 \%, 98.0 \%$ and $100 \%$ for tembotrione; $100 \%, 98.7 \%$ and $100 \%$ for flumioxazin + tembotrione; $100 \%, 100 \%$ and $100 \%$ for s-metolachlor + atrazine + tembotrione; and $98.7 \%, 98.7 \%$ and $99.7 \%$ for atrazine + tembotrione, respectively to the BRS 509, BRS 506 and BRS 511 cultivars. Tembotrione, flumioxazin + tembotrione, atrazine + s-metolachlor + tembotrione and atrazine + tembotrione showed a good control rate of Ipomoea indivisa, Digitaria ciliaris and Urochloa plantaginea, but did not present selectivity to the sorghum cultivars. Atrazine, in general, showed higher selectivity to the yield components of the BRS 509 and BRS 506 cultivars.

KEY-WORDS: Sorghum bicolor; Ipomoea indivisa; Digitaria ciliaris; Urochloa plantaginea.

\section{INTRODUCTION}

The cultivation of sweet sorghum [Sorghum bicolor (L.) Moench.] stands out as an interesting alternative for ethanol production in sugarcane reform areas or in non-preferred sites for the cultivation of

\section{RESUMO}

Seletividade e eficiência de herbicidas no controle de plantas daninhas infestantes do sorgo sacarino

A carência de herbicidas registrados para o controle de plantas daninhas, em sorgo sacarino, torna-se fator limitante à produção. Objetivou-se avaliar a seletividade de herbicidas em sorgo sacarino e a eficiência no controle de plantas daninhas. $\mathrm{O}$ delineamento experimental foi de blocos ao acaso, com quarto repetições. Os tratamentos incluíram cultivares de sorgo sacarino (BRS 506, BRS 509 e BRS 511) e herbicidas aplicados isoladamente em pré-emergência (atrazine - $1.500 \mathrm{~g} \mathrm{ha}^{-1}$; atrazine + s-metolachlor $1.665 \mathrm{~g} \mathrm{ha}^{-1}+1.035 \mathrm{~g} \mathrm{ha}^{-1}$; flumioxazin - $50 \mathrm{~g} \mathrm{ha}^{-1}$; s-metolachlor $1.440 \mathrm{~g} \mathrm{ha}^{-1}$ ) e pós-emergência (tembotrione - $100,8 \mathrm{~g} \mathrm{ha}^{-1}$ ) e de forma sequencial em pré e pós-emergência (atrazine $+\mathrm{s}$-metolachlor + tembotrione $-1.665 \mathrm{~g} \mathrm{ha}^{-1}+1.035 \mathrm{~g} \mathrm{ha}^{-1}+100,8 \mathrm{~g} \mathrm{ha}^{-1}$; atrazine + tembotrione $-1.500 \mathrm{~g} \mathrm{ha}^{-1}+100,8 \mathrm{~g} \mathrm{ha}^{-1}$; flumioxazin + tembotrione $50 \mathrm{~g} \mathrm{ha}^{-1}+100,8 \mathrm{~g} \mathrm{ha}^{-1}$ ), mais duas testemunhas, uma capinada e outra sem capina. A fitotoxicidade ao sorgo foi de $98,0 \%, 98,0 \%$ e $100 \%$ de tembotrione; $100 \%, 98,7 \%$ e $100 \%$ de flumioxazin + tembotrione; $100 \%, 100 \%$ e $100 \%$ de atrazine + s-metolachlor + tembotrione; e 98,7 \%, 98,7\% e 99,7\% de atrazine + tembotrione, respectivamente para as cultivares BRS 509, BRS 506 e BRS 511. Tembotrione, flumioxazin + tembotrione, atrazine + s-metolachlor + tembotrione e atrazine + tembotrione apresentaram bom controle de Ipomoea indivisa, Digitaria ciliaris e Urochloa plantaginea, porém, não demonstraram seletividade às cultivares de sorgo. $\mathrm{O}$ atrazine, de modo geral, apresentou maior seletividade aos componentes de rendimento das cultivares BRS 509 e BRS 506.

PALAVRAS-CHAVE: Sorghum bicolor; Ipomoea indivisa; Digitaria ciliaris; Urochloa plantaginea.

sugarcane. The short cycle of 90-120 days, ease of mechanization and high levels of fermentable sugars present in the stalk favor the use of sweet sorghum (Ratnavathi et al. 2010). However, in order to consolidate this crop, in Brazil, it is important that cultural practices be carried out properly. Among

1. Manuscript received in Jan./2016 and accepted for publication in May./2016 (http://dx.doi.org/10.1590/1983-40632016v4639431).

2. Universidade Federal da Fronteira Sul, Erechim, RS, Brazil.E-mails: leandro.galon@uffs.edu.br, fran_ffernandes@hotmail.com, cesartiagoforte@hotmail.com.

3. Empresa Brasileira de Pesquisa Agropecuária (Embrapa Clima Temperado), Pelotas, RS, Brazil. E-mail: andre.andres@embrapa.br. 4. Empresa Brasileira de Pesquisa Agropecuária (Embrapa Milho e Sorgo), Sete Lagoas, MG, Brazil. 
them, the weed management stands out as one of the limiting production factors, due to the slow initial growth of sweet sorghum and scarcity of herbicides registered for use in this crop (Silva et al. 2014a).

The lack of weed control can result in yield losses. A reduction of approximately $50 \%$ in the mass of stalks was observed during the crop cycle by Silva et al. (2014b), in the absence of weed control. This fact demonstrates the susceptibility of sweet sorghum to weed interference and the need of a good weed management, so the crop can express its full productive potential.

The active ingredient atrazine is one of the few herbicides registered for use in sorghum (Rodrigues \& Almeida 2011). This product is characterized as an inhibitor of photosystem II, registered for use in pre- and/or early post-emergence, being effective in dicotyledonous and some grasses (Rodrigues \& Almeida 2011). Thus, the search for other molecules that can be used for the weed chemical management in sorghum has great importance for the consolidation and expansion of this crop in Brazil.

With the recent classification of sorghum as a crop with insufficient phytosanitary support (minor crop) (ABCSM 2014), it has been less costly for agrochemical companies to request the extension of use of plant protection products registered for weed control in maize and sorghum. Thus, studies demonstrating the selectivity and efficiency of herbicides registered to maize and sorghum crops are of great importance to support the requests of extension of use by agrochemical manufacturers.

This study aimed at evaluating the selectivity of herbicides on sweet sorghum and their efficiency on weed control.

\section{MATERIAL AND METHODS}

A field experiment was conducted at the experimental area of the Universidade Federal da Fronteira Sul, in Erechim, Rio Grande do Sul State, Brazil, during the 2014/2015 season.

The soil of the experimental area is classified as an Oxisol, mapping unit Erechim (Streck et al. 2008). The $\mathrm{pH}$ correction and soil fertilization were performed according to the soil physicochemical analysis and technical recommendations for the sorghum crop (ROLAS 2004). The soil physical and chemical characteristics were: $\mathrm{pH}$ (water) 4.8;
$\mathrm{OM}=3.5 \% ; \mathrm{P}=4.0 \mathrm{mg} \mathrm{dm}{ }^{-3} ; \mathrm{K}=117.0 \mathrm{mg} \mathrm{dm}^{-3}$; $\mathrm{Al}^{3+}=0.6 \mathrm{cmol}_{\mathrm{c}} \mathrm{dm}^{-3} ; \mathrm{Ca}^{2+}=4.7 \mathrm{cmol}_{\mathrm{c}} \mathrm{dm}^{-3} ; \mathrm{Mg}^{2+}=$ $1.8 \mathrm{cmol}_{\mathrm{c}} \mathrm{dm}^{-3} ; \mathrm{CEC}(\mathrm{t})=7.4 \mathrm{cmol}_{\mathrm{c}} \mathrm{dm}^{-3} ; \operatorname{CEC}\left(\mathrm{T}_{\mathrm{pH}=7.0}\right)=$ $16.5 \mathrm{cmol}_{\mathrm{c}} \mathrm{dm}^{-3} ; \mathrm{H}+\mathrm{Al}=9.7 \mathrm{cmol}_{\mathrm{c}} \mathrm{dm}^{-3} ; \mathrm{SB}=$ $6.8 \mathrm{cmol}_{\mathrm{c}} \mathrm{dm}^{-3} ; \mathrm{V}=41 \%$; and clay $=60 \%$.

The experiment was conducted in a randomized blocks design, in a $3 \times 10$ factorial scheme, with four replications. The Factor A corresponded to the sweet sorghum cultivars (BRS 509, BRS 506 and BRS 511), while the Factor B consisted of herbicides applied either uniquely at pre-emergence (atrazine - 1,500 $\mathrm{g} \mathrm{ha}^{-1}$; atrazine $+\mathrm{s}$-metolachlor $1,665 \mathrm{~g} \mathrm{ha}^{-1}+1,035 \mathrm{~g} \mathrm{ha}^{-1}$; flumioxazin - $50 \mathrm{~g} \mathrm{ha}^{-1}$; s-metolachlor - 1,440 $\mathrm{g} \mathrm{ha}^{-1}$ ) and post-emergence (tembotrione - $100.8 \mathrm{~g} \mathrm{ha}^{-1}$ ) or sequentially at preand post-emergence (atrazine $+\mathrm{s}$-metolachlor + tembotrione - $1,665 \mathrm{~g} \mathrm{ha}^{-1}+1,035 \mathrm{~g} \mathrm{ha}^{-1}+100.8 \mathrm{~g} \mathrm{ha}^{-1}$; tembotrione + atrazine $-1,500 \mathrm{~g} \mathrm{ha}^{-1}+100.8 \mathrm{~g} \mathrm{ha}^{-1}$; flumioxazin + tembotrione $\left.-50 \mathrm{~g} \mathrm{ha}^{-1}+100.8 \mathrm{~g} \mathrm{ha}^{-1}\right)$, plus two controls, one weeded and one unweeded. Each experimental unit was characterized by a plot of $12.50 \mathrm{~m}^{2}(5.00 \mathrm{~m} \times 2.50 \mathrm{~m})$, seeded with five rows of sweet sorghum, spaced $0.50 \mathrm{~m}$ apart, at a density of 200,000 plants ha-1.

The characteristics of the three sorghum cultivars used in the experiment (Brasil 2016) are: BRS 511 - can achieve yield of $80 \mathrm{t} \mathrm{ha}^{-1}$ of stem, associated with high levels of fermentable sugars in the juice $\left(18-22^{\circ}\right.$ Brix $)$ and good fermentation pattern, and moderate resistance to anthracnose and leaf blotch; BRS 509 - shows stable production and high levels of fermentable sugars in the juice (average of $18^{\circ}$ Brix), with great fermentation pattern, associated with a low production cost and a potential stem production of $60 \mathrm{t} \mathrm{ha}^{-1}$; BRS 506 - has 120 days of development cycle and supports a larger number of plants per area, when compared to the others.

Herbicide application was made by an accurate $\mathrm{CO}^{2}$ pressurized sprayer equipped with four spray nozzles fan type DG 110.02, maintaining a constant pressure of $2.8 \mathrm{kgf} \mathrm{cm}^{-2}$, at a travel speed of $3.6 \mathrm{~km} \mathrm{~h}^{-1}$, which provided a flow of herbicidal spray solution of $200 \mathrm{~L} \mathrm{ha}^{-1}$. The environmental conditions at the time of the application in pre- and/or post-emergence are listed in Table 1.

At the time of application of the post-emergence herbicides, the weeds Urochloa plantaginea (Alexander grass) and Digitaria ciliaris (southern crabgrass) were in the two leaves to two tillers stage, while Ipomoea indivisa (morning-glory) was in the 
two to four leaves stage, with an estimated population of 136 plants $\mathrm{m}^{-2}, 128$ plants $\mathrm{m}^{-2}$ and 32 plants $\mathrm{m}^{-2}$, respectively. The sorghum plants presented 3-6 fully developed leaves. The data of accumulated precipitation and temperature are shown in Figure 1.

As topdressing, $150 \mathrm{~kg} \mathrm{ha}^{-1}$ of nitrogen were used in the form of urea, applied at the row, when the sorghum cultivars had 4-6 fully expanded leaves. At 35 days after the herbicide application, the control of $U$. plantaginea, D. ciliares and I. indivisa, as well as the phytotoxicity to the culture, were visually measured by two evaluators, in a percentage scale. For this, zero $(0 \%)$ was attributed to the treatment with no weed control and no phytotoxicity to the crop, and one hundred (100\%) to the treatment with total weed control or sweet sorghum plant death (SBCPD 1995).

Height (measured with the aid of a ruler graduated in $\mathrm{cm}$, from the soil ground to the last leaf), stalk diameter (measured using a caliper, in $\mathrm{mm}$, considering the first internode of the plant) and total green mass of the sorghum plants were evaluated 120 days after the crop emergence, at harvest time. Plant weight was determined by cutting the plants contained in an area of $3.00 \mathrm{~m} \times 1.50 \mathrm{~m}\left(4.50 \mathrm{~m}^{2}\right)$ and weighing the material with the aid of an analytical balance.

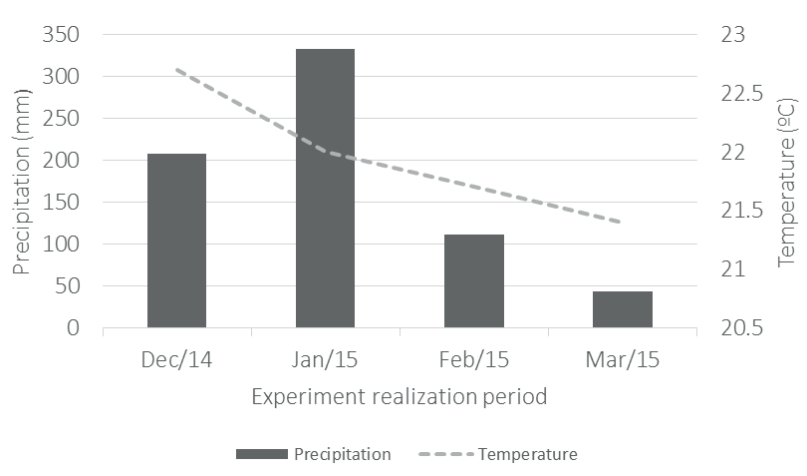

Figure 1. Accumulated precipitation (bars in $\mathrm{mm}$ ) and monthly temperature (dotted line in ${ }^{\circ} \mathrm{C}$ ) at the site and time spam of the experiment, in Erechim, Rio Grande do Sul State, Brazil. Source: Brasil (2015).
In order to evaluate normality, the data were subjected to the Shapiro-Wilk test $(p \geq 0.05)$ and, when the normality assumption was verified, an analyses of variance was carried out, and the comparison of significantly different treatments was done using the Tukey test $(\mathrm{p} \leq 0.05)$.

\section{RESULTS AND DISCUSSION}

There was a significant interaction between sorghum cultivars and herbicides for all variables. The visual assessment of crop phytotoxicity by herbicides (Table 2) shows that the tembotrione (100.8 $\mathrm{g} \mathrm{ha}^{-1}$ ), applied alone or combined, caused the death of plants (BRS 506, BRS 509 and BRS 511 cultivars). Minor phytotoxicity levels are provided by the flumioxazin (50 $\left.\mathrm{g} \mathrm{ha}^{-1}\right)$ and atrazine $\left(1,500 \mathrm{~g} \mathrm{ha}^{-1}\right)$ herbicides applied uniquely at pre-emergence. These herbicides promoted initial chlorosis, but the symptoms have disappeared with the development of the plants. The s-metolachlor herbicide $\left(1,440 \mathrm{~g} \mathrm{ha}^{-1}\right)$ applied uniquely at pre-emergence or via a commercially available mix with atrazine $\left(1,500 \mathrm{~g} \mathrm{ha}^{-1}\right)$ promoted the swelling of tissues and stem winding of some plants, causing reduction in growth and plant stand failures, both due to the death of seedlings that failed to develop (Table 5).

In general, the cultivars showed similar phytotoxicity levels to each other, to the tested molecules, except for BRS 509, which demonstrated greater phytotoxicity to the s-metolachlor herbicide $\left(1,440 \mathrm{~g} \mathrm{ha}^{-1}\right)$ applied alone or in combination with atrazine $\left(1,500 \mathrm{~g} \mathrm{ha}^{-1}\right)$. The differential tolerance of sorghum cultivars to herbicides is due to a genetic variation, which can result in morphological and physiological differences in plants, affecting the absorption, translocation and metabolism of herbicides (Bunting et al. 2004, Armel et al. 2005).

The susceptibility of sweet sorghum cultivars to tembotrione diverges from the results obtained by Dan et al. (2010), who found a greater selectivity of this herbicide when applied at low doses (42-88 $\left.\mathrm{g} \mathrm{ha}^{-1}\right)$

Table 1. Environmental conditions at the time of treatments application in pre- and post-emergence.

\begin{tabular}{|c|c|c|c|c|c|}
\hline \multirow{2}{*}{ Application time } & Luminosity & Temperature & Relative humidity & \multirow{2}{*}{$\begin{array}{c}\text { Soil } \\
\text { conditions }\end{array}$} & Wind speed \\
\hline & $\%$ & ${ }^{\circ} \mathrm{C}$ & $\%$ & & $\mathrm{~km} \mathrm{~h}^{-1}$ \\
\hline Pre-emergence & 90 & 29.2 & 51 & Moist & $2-4$ \\
\hline Post-emergence & 100 & 28.0 & 67 & Moist & $4-8$ \\
\hline
\end{tabular}


and in the more advanced stages of development ( 8 leaves), for the AG-1040 sorghum cultivar. This cultivar differs from the ones obtained in this study. The s-metolachlor herbicide $\left(1,875 \mathrm{~g} \mathrm{ha}^{-1}\right)$ is registered for the sorghum crop in some countries, but always associated with the use of a safener to assist the crop in the degradation of the herbicide molecule (Silva et al. 2014b).

Martins et al. (2006) evaluated the selectivity of metolachlor $\left(2,520 \mathrm{~g} \mathrm{ha}^{-1}\right)$ and alachlor herbicides $\left(2,800 \mathrm{~g} \mathrm{ha}^{-1}\right)$ to the A-6304 sorghum cultivar and observed severe symptoms of phytotoxicity, as well as failures in the final plant stand, corroborating the results found in this study. Researches that address the selectivity of flumioxazin to sorghum cultivars are non-existent in the literature. In this study, flumioxazin $\left(50 \mathrm{~g} \mathrm{ha}^{-1}\right)$ showed selectivity to the sweet sorghum cultivars, but unsatisfactory weed control (Table 3).

The results show that tembotrione $\left(100.8 \mathrm{~g} \mathrm{ha}^{-1}\right)$ applied alone or associated with other herbicides molecules provided a better control (up to $99.7 \%$ ) for all weeds evaluated: I. indivisa, D. ciliaris and $U$. plantaginea (Table 3). Despite the good weed control, its application is not recommended for the BRS 506, BRS 509 and BRS 511 sweet sorghum cultivars, as tembotrione caused severe symptoms of phytotoxicity (above $98 \%$ ).

To control I. indivisa, atrazine $\left(1,500 \mathrm{~g} \mathrm{ha}^{-1}\right)$ applied individually or sequentially with s-metolachlor+ tembotrione $\left(1,440 \mathrm{~g} \mathrm{ha}^{-1}+100.8 \mathrm{~g} \mathrm{ha}^{-1}\right)$ provided control levels similar to tembotrione $\left(100.8 \mathrm{~g} \mathrm{ha}^{-1}\right)$ applied alone. On the other hand, the mixture of atrazine $+\mathrm{s}$-metolachlor $\left(1,665 \mathrm{~g} \mathrm{ha}^{-1}+1,035 \mathrm{~g} \mathrm{ha}^{-1}\right)$, and flumioxazin $\left(50 \mathrm{~g} \mathrm{ha}^{-1}\right)$ and s-metolachlor $\left(1,440 \mathrm{~g} \mathrm{ha}^{-1}\right)$ applied alone did not control this infesting species (Table 3 ).

The absence of control of I. indivisa by flumioxazin $\left(50 \mathrm{~g} \mathrm{ha}^{-1}\right)$ is aligned with the fact that this herbicide is not registered for controlling this weed, but for the control of I. grandifolia, I. nil and I. purpurea (Rodrigues \& Almeida 2011). In the same way, s-metolachlor $\left(1,440 \mathrm{~g} \mathrm{ha}^{-1}\right)$ was not expected to control I. indivisa, as it is not registered for controlling this species (Rodrigues \& Almeida 2011). The fact that the commercial mixture of atrazine + s-metolachlor $\left(1,665 \mathrm{~g} \mathrm{ha}^{-1}+\right.$ $1,035 \mathrm{~g} \mathrm{ha}^{-1}$ ) did not cause any control of I. indivisa is also aligned with the fact that this product has no record for the control of this weed (Rodrigues \& Almeida 2011). It is hypothesized that the lack of effectiveness on the I. indivisa control, by mixing the two herbicides, may be associated with any physical or biological incompatibility that occurs between molecules (antagonism). There are studies reporting the occurrence of this antagonism, when applying determined mixtures on certain species, according to the mode of application, stage of plant development, spray volume and product dose, among others (Jordan \& Warren 1995, Werlang \& Silva 2002, Maciel et al. 2013, Costa et al. 2014).

The s-metolachlor herbicide, when applied alone, resulted in control levels of $D$. ciliaris between $84.3 \%$ and $87.5 \%$, among the sorghum cultivars, not differing statistically from each other. However,

Table 2. Phytotoxicity of sweet sorghum cultivars, 35 days after the herbicide application.

\begin{tabular}{|c|c|c|c|c|c|}
\hline \multirow{3}{*}{ Treatment } & \multirow{3}{*}{$\begin{array}{c}\text { Dose } \\
\left(\mathrm{g} \mathrm{ha}^{-1}\right)\end{array}$} & \multirow{3}{*}{$\begin{array}{l}\text { Application } \\
\text { time }\end{array}$} & \multicolumn{3}{|c|}{ Cultivar } \\
\hline & & & BRS 509 & BRS 506 & BRS 511 \\
\hline & & & \multicolumn{3}{|c|}{ Phytotoxicity (\%) } \\
\hline Atrazine & 1,500 & Pre $^{1}$ & $8.0 \mathrm{cdA}^{3}$ & $9.0 \mathrm{dA}$ & $5.0 \mathrm{~dB}$ \\
\hline Atrazine $+\mathrm{s}$-metolachlor & $1,665+1,035$ & Pre & $10.0 \mathrm{bcC}$ & $77.5 \mathrm{bA}$ & $50.0 \mathrm{cB}$ \\
\hline Flumioxazin & 50 & Pre & $5.5 \mathrm{dA}$ & $0.0 \mathrm{eB}$ & $0.0 \mathrm{eB}$ \\
\hline S-metolachlor & 1,440 & Pre & $12.3 \mathrm{bC}$ & $60.0 \mathrm{cB}$ & $87.7 \mathrm{bA}$ \\
\hline Tembotrione & 100.8 & Post & $98.0 \mathrm{aA}$ & $98.0 \mathrm{aA}$ & $100.0 \mathrm{aA}$ \\
\hline Atrazine + s-metolachlor + tembotrione & $1,665+1,035+100.8$ & Pre + post $^{2}$ & $100.0 \mathrm{aA}$ & $100.0 \mathrm{aA}$ & $100.0 \mathrm{aA}$ \\
\hline Atrazine + tembotrione & $1,500+100.8$ & Pre + post & $98.7 \mathrm{aA}$ & $98.7 \mathrm{aA}$ & $99.7 \mathrm{aA}$ \\
\hline Flumioxazin + tembotrione & $50+100.8$ & Pre + post & $100.0 \mathrm{aA}$ & $98.7 \mathrm{aA}$ & $100.0 \mathrm{aA}$ \\
\hline Weeded control & - & - & $0.0 \mathrm{eA}$ & $0.0 \mathrm{eA}$ & $0.0 \mathrm{eA}$ \\
\hline General average & - & - & & 56.15 & \\
\hline $\mathrm{CV}(\%)$ & - & - & & 2.54 & \\
\hline
\end{tabular}

${ }^{1}$ Single application; ${ }^{2}$ sequential application; ${ }^{3}$ averages followed by the same lowercase letter, in the columns, and uppercase letter, in the lines, do not differ by the Tukey test at $5 \%$. 
the efficiency of this herbicide for the control of $U$. plantaginea decreased dramatically, with values ranging from $33.3 \%$ to $40 \%$, depending on the cultivar. The average control level of $U$. plantaginea increased to 48.3-70\%, when s-metolachlor was applied in combination with atrazine.

The difference observed between the control of $U$. plantaginea and D. ciliaris may be associated with their differential susceptibility to the herbicide, as it was also verified by Zagonel et al. (1999), when testing the effectiveness of propaquizafop and fluazifop-p-butyl for the control of Alexander grass, D. ciliaris and Eleusine indica. It is noteworthy that the $U$. plantaginea seed bank was bigger than the $D$. ciliares one in the experimental area, what may have contributed to the reinfestation of the experimetal plots with the reduction of the herbicide residual with time.

Table 3. Control of Ipomoea indivisa, Digitaria ciliaris and Urochloa plantaginea on sweet sorghum cultivars, 35 days after the herbicide application.

\begin{tabular}{|c|c|c|c|c|c|}
\hline \multirow{3}{*}{ Treatment } & \multirow{3}{*}{ Dose $\left(\mathrm{g} \mathrm{ha}^{-1}\right)$} & \multirow{3}{*}{ Application time } & \multicolumn{3}{|c|}{ Cultivar } \\
\hline & & & BRS 509 & BRS 506 & BRS 511 \\
\hline & & & \multicolumn{3}{|c|}{ Control of Ipomoea indivisa (\%) } \\
\hline Atrazine & 1,500 & Pre $^{1}$ & $100.0 \mathrm{aA}^{3}$ & $99.7 \mathrm{aA}$ & $100.0 \mathrm{aA}$ \\
\hline Atrazine $+\mathrm{s}$-metolachlor & $1,665+1,035$ & Pre & $0.0 \mathrm{bA}$ & $0.0 \mathrm{bA}$ & $0.0 \mathrm{bA}$ \\
\hline Flumioxazin & 50 & Pre & $0.0 \mathrm{bA}$ & $0.0 \mathrm{bA}$ & $0.0 \mathrm{bA}$ \\
\hline S-metolachlor & 1,440 & Pre & $0.0 \mathrm{bA}$ & $0.0 \mathrm{bA}$ & $0.0 \mathrm{bA}$ \\
\hline Tembotrione & 100.8 & Post & $99.7 \mathrm{aA}$ & $99.7 \mathrm{aA}$ & $99.7 \mathrm{aA}$ \\
\hline Atrazine + s-metolachlor + tembotrione & $1,665+1,035+100.8$ & Pre + post $^{2}$ & $99.7 \mathrm{aA}$ & $99.7 \mathrm{aA}$ & $99.7 \mathrm{aA}$ \\
\hline Atrazine + tembotrione & $1,500+100.8$ & Pre + post & $99.7 \mathrm{aA}$ & $99.7 \mathrm{aA}$ & $99.7 \mathrm{aA}$ \\
\hline Flumioxazin + tembotrione & $50+100.8$ & Pre + post & $99.7 \mathrm{aA}$ & $99.7 \mathrm{aA}$ & $99.7 \mathrm{aA}$ \\
\hline Unweeded control & - & - & $0.0 \mathrm{bA}$ & $0.0 \mathrm{bA}$ & $0.0 \mathrm{bA}$ \\
\hline Weeded control & - & - & $100.0 \mathrm{aA}$ & $100.0 \mathrm{aA}$ & $100.0 \mathrm{aA}$ \\
\hline General average & - & - & \multicolumn{3}{|c|}{56.64} \\
\hline $\mathrm{CV}(\%)$ & - & - & \multicolumn{3}{|c|}{0.26} \\
\hline Treatment & Dose $\left(\mathrm{g} \mathrm{ha}^{-1}\right)$ & Application time & \multicolumn{3}{|c|}{ Control of Digitaria ciliaris (\%) } \\
\hline Atrazine & 1,500 & Pre $^{1}$ & $70.0 \mathrm{cA}^{3}$ & $35.0 \mathrm{cB}$ & $27.5 \mathrm{cC}$ \\
\hline Atrazine $+\mathrm{s}$-metolachlor & $1,665+1,035$ & Pre & $90.0 \mathrm{bA}$ & $78.3 \mathrm{bB}$ & $85.0 \mathrm{bA}$ \\
\hline Flumioxazin & 50 & Pre & $0.0 \mathrm{eA}$ & $0.0 \mathrm{dA}$ & $0.0 \mathrm{dA}$ \\
\hline S-metolachlor & 1,440 & Pre & $87.5 \mathrm{bA}$ & $84.3 \mathrm{bA}$ & $85.0 \mathrm{bA}$ \\
\hline Tembotrione & 100.8 & Post & $100.0 \mathrm{aA}$ & $100.0 \mathrm{aA}$ & $100.0 \mathrm{aA}$ \\
\hline Atrazine + s-metolachlor + tembotrione & $1,665+1,035+100.8$ & Pre + post $^{2}$ & $100.0 \mathrm{aA}$ & $100.0 \mathrm{aA}$ & $100.0 \mathrm{aA}$ \\
\hline Atrazine + tembotrione & $1,500+100.8$ & Pre + post & $100.0 \mathrm{aA}$ & $100.0 \mathrm{aA}$ & $100.0 \mathrm{aA}$ \\
\hline Flumioxazin + tembotrione & $50+100.8$ & Pre + post & $100.0 \mathrm{aA}$ & $100.0 \mathrm{aA}$ & $100.0 \mathrm{aA}$ \\
\hline Unweeded control & - & - & $0.0 \mathrm{eA}$ & $0.0 \mathrm{dA}$ & $0.0 \mathrm{dA}$ \\
\hline Weeded control & - & - & $100.0 \mathrm{aA}$ & $100.0 \mathrm{aA}$ & $100.0 \mathrm{aA}$ \\
\hline General average & - & - & \multicolumn{3}{|c|}{71.42} \\
\hline $\mathrm{CV}(\%)$ & - & - & \multicolumn{3}{|c|}{4.35} \\
\hline Treatment & Dose $\left(\mathrm{g} \mathrm{ha}^{-1}\right)$ & Application time & \multicolumn{3}{|c|}{ Control of Urochloa plantaginea (\%) } \\
\hline Atrazine & 1,500 & Pre $^{1}$ & $70.0 \mathrm{bA}^{3}$ & $37.5 \mathrm{cB}$ & $27.5 \mathrm{dC}$ \\
\hline Atrazine $+\mathrm{s}$-metolachlor & $1,665+1,035$ & Pre & $70.0 \mathrm{bA}$ & $53.3 \mathrm{bB}$ & $48.3 \mathrm{bB}$ \\
\hline Flumioxazin & 50 & Pre & $0.0 \mathrm{dA}$ & $0.0 \mathrm{dA}$ & $0.0 \mathrm{eA}$ \\
\hline S-metolachlor & 1,440 & Pre & $40.0 \mathrm{cA}$ & $33.3 \mathrm{cA}$ & $37.5 \mathrm{cA}$ \\
\hline Tembotrione & 100.8 & Post & $100.0 \mathrm{aA}$ & $100.0 \mathrm{aA}$ & $100.0 \mathrm{aA}$ \\
\hline Atrazine + s-metolachlor + tembotrione & $1,665+1,035+100.8$ & Pre + post $^{2}$ & $100.0 \mathrm{aA}$ & $100.0 \mathrm{aA}$ & $100.0 \mathrm{aA}$ \\
\hline Atrazine + tembotrione & $1,500+100.8$ & Pre + post & $100.0 \mathrm{aA}$ & $100.0 \mathrm{aA}$ & $100.0 \mathrm{aA}$ \\
\hline Flumioxazin + tembotrione & $50+100.8$ & Pre + post & $100.0 \mathrm{aA}$ & $100.0 \mathrm{aA}$ & $100.0 \mathrm{aA}$ \\
\hline Unweeded control & - & - & $0.0 \mathrm{dA}$ & $0.0 \mathrm{dA}$ & $0.0 \mathrm{eA}$ \\
\hline Weeded control & - & - & $100.0 \mathrm{aA}$ & $100.0 \mathrm{aA}$ & $100.0 \mathrm{aA}$ \\
\hline General average & - & - & \multicolumn{3}{|c|}{63.92} \\
\hline CV $(\%)$ & - & - & \multicolumn{3}{|c|}{5.64} \\
\hline
\end{tabular}


The control levels of $D$. ciliaris and $U$. plantaginea were differentiated according to the sweet sorghum cultivar used (Table 3 ). In the treatment with a mixture of atrazine + s-metolachlor $\left(1,665 \mathrm{~g} \mathrm{ha}^{-1}+1,035 \mathrm{~g} \mathrm{ha}^{-1}\right)$, it was found a better $U$. plantaginea control rate, when this herbicide was applied on the BRS 509 cultivar. This cultivar resulted in higher plant density, when compared to the others (Table 5), what may have led to a greater shading of weeds. Furthermore, this behavior may be associated with specific features of each cultivar. For example, the architecture and leaf area can influence the interrow shading, thus assisting in the weed community control in this area.

The cultivars yield components showed different behavior to the herbicide treatments, what can be attributed to the intrinsic ability of each cultivar to grow under competition with weeds and/or due to differential susceptibility to these herbicides.
Plant height and stem diameter exhibited similar behavior (Table 4). The BRS 509, BRS 506 and BRS 511 cultivars were negatively affected by the death of plants, when tembotrione $\left(100.8 \mathrm{~g} \mathrm{ha}^{-1}\right)$, flumioxazin + tembotrione $\left(50 \mathrm{~g} \mathrm{ha}^{-1}+\right.$ $\left.100.8 \mathrm{~g} \mathrm{ha}^{-1}\right)$, atrazine $+\mathrm{s}$-metolachlor + tembotrione $\left(1,665 \mathrm{~g} \mathrm{ha}^{-1}+1,035 \mathrm{~g} \mathrm{ha}^{-1}+100.8 \mathrm{~g} \mathrm{ha}^{-1}\right)$ and atrazine + tembotrione $\left(1,500 \mathrm{~g} \mathrm{ha}^{-1}+100.8 \mathrm{~g} \mathrm{ha}^{-1}\right)$ were applied.

Atrazine was the only herbicide that did not provide a smaller increase in height and stalk diameter, for the BRS 509 and BRS 506 cultivars, being equivalent to the weeded control (Table 4). For the BRS 511, it was found that plant height and stalk diameter were not adversely affected by the application of atrazine $+\mathrm{s}$-metolachlor $\left(1,665 \mathrm{~g} \mathrm{ha}^{-1}+\right.$ $\left.1,035 \mathrm{~g} \mathrm{ha}^{-1}\right)$ and s-metolachlor $\left(1,440 \mathrm{~g} \mathrm{ha}^{-1}\right)$, which were equal to the treatment without herbicide application (weeded control). Besides being negatively affected by atrazine $\left(1,500 \mathrm{~g} \mathrm{ha}^{-1}\right)$, the stem

Table 4. Height and stem diameter of the sweet sorghum cultivars due to the application of herbicides.

\begin{tabular}{|c|c|c|c|c|c|}
\hline \multirow{3}{*}{ Treatment } & \multirow{3}{*}{ Dose $\left(\mathrm{g} \mathrm{ha}^{-1}\right)$} & \multirow{3}{*}{ Application time } & \multicolumn{3}{|c|}{ Cultivar } \\
\hline & & & BRS 509 & BRS 506 & BRS 511 \\
\hline & & & \multicolumn{3}{|c|}{ Plant height $(\mathrm{m})$} \\
\hline Atrazine & 1,500 & Pre $^{1}$ & $2.87 \mathrm{abAB}^{3}$ & $2.96 \mathrm{aA}$ & $2.71 \mathrm{bB}$ \\
\hline Atrazine + s-metolachlor & $1,665+1,035$ & Pre & $2.90 \mathrm{abA}$ & $2.51 \mathrm{cB}$ & $3.01 \mathrm{aA}$ \\
\hline Flumioxazin & 50 & Pre & $2.68 \mathrm{bcAB}$ & $2.54 \mathrm{cB}$ & $2.85 \mathrm{abA}$ \\
\hline S-metolachlor & 1,440 & Pre & $2.98 \mathrm{aA}$ & $2.86 \mathrm{abA}$ & $2.99 \mathrm{aA}$ \\
\hline Tembotrione & 100.8 & Post & $0.00 \mathrm{dA}$ & $0.00 \mathrm{dA}$ & $0.00 \mathrm{cA}$ \\
\hline Atrazine $+\mathrm{s}$-metolachlor + tembotrione & $1,665+1,035+100.8$ & Pre + post $^{2}$ & $0.00 \mathrm{dA}$ & $0.00 \mathrm{dA}$ & $0.00 \mathrm{cA}$ \\
\hline Atrazine + tembotrione & $1,500+100.8$ & Pre + post & $0.00 \mathrm{dA}$ & $0.00 \mathrm{dA}$ & $0.00 \mathrm{cA}$ \\
\hline Flumioxazin + tembotrione & $50+100.8$ & Pre + post & $0.00 \mathrm{dA}$ & $0.00 \mathrm{dA}$ & $0.00 \mathrm{cA}$ \\
\hline Unweeded control & - & - & $2.58 \mathrm{cB}^{1}$ & $2.63 \mathrm{bcB}$ & $2.89 \mathrm{abA}$ \\
\hline Weeded control & - & - & $2.87 \mathrm{abB}$ & $2.92 \mathrm{aAB}$ & $3.05 \mathrm{aA}$ \\
\hline General average & - & - & \multicolumn{3}{|c|}{1.69} \\
\hline $\mathrm{CV}(\%)$ & - & - & \multicolumn{3}{|c|}{5.06} \\
\hline Treatment & Dose $\left(\mathrm{g} \mathrm{ha}^{-1}\right)$ & Application time & \multicolumn{3}{|c|}{ Stem diameter $(\mathrm{cm})$} \\
\hline Atrazine & 1,500 & Pre $^{1}$ & $1.37 \mathrm{aA}^{3}$ & $1.51 \mathrm{abA}$ & $1.43 \mathrm{cA}$ \\
\hline Atrazine + s-metolachlor & $1,665+1,035$ & Pre & $1.30 \mathrm{aB}$ & $1.4 \mathrm{bB}$ & $1.80 \mathrm{aA}$ \\
\hline Flumioxazin & 50 & Pre & $1.47 \mathrm{aA}$ & $1.35 \mathrm{bA}$ & $1.47 \mathrm{bcA}$ \\
\hline S-metolachlor & 1,440 & Pre & $1.43 \mathrm{aB}$ & $1.29 \mathrm{bB}$ & $1.67 \mathrm{abA}$ \\
\hline Tembotrione & 100.8 & Post & $0.00 \mathrm{cA}$ & $0.00 \mathrm{cA}$ & $0.00 \mathrm{dA}$ \\
\hline Atrazine + s-metolachlor + tembotrione & $1,665+1,035+100.8$ & Pre + post $^{2}$ & $0.00 \mathrm{cA}$ & $0.00 \mathrm{cA}$ & $0.00 \mathrm{dA}$ \\
\hline Atrazine + tembotrione & $1,500+100.8$ & Pre + post & $0.00 \mathrm{cA}$ & $0.00 \mathrm{cA}$ & $0.00 \mathrm{dA}$ \\
\hline Flumioxazin + tembotrione & $50+100.8$ & Pre + post & $0.00 \mathrm{cA}$ & $0.00 \mathrm{cA}$ & $0.00 \mathrm{dA}$ \\
\hline Unweeded control & - & - & $1.04 \mathrm{bB}$ & $1.39 \mathrm{bA}$ & $1.46 \mathrm{bcA}$ \\
\hline Weeded control & - & - & $1.51 \mathrm{aB}$ & $1.67 \mathrm{aAB}$ & $1.84 \mathrm{aA}$ \\
\hline General average & - & - & & 0.88 & \\
\hline $\mathrm{CV}(\%)$ & - & - & & 9.99 & \\
\hline
\end{tabular}


diameter of the BRS 511 cultivar was also affected by flumioxazin $\left(50 \mathrm{~g} \mathrm{ha}^{-1}\right)$.

The plant stand of the sweet sorghum cultivars was not affected by the application of atrazine $\left(1,500 \mathrm{~g} \mathrm{ha}^{-1}\right)$. Flumioxazin $\left(50 \mathrm{~g} \mathrm{ha}^{-1}\right)$ had no effect on BRS 509 and BRS 506 (Table 5). In contrast, the treatments containing atrazine $+\mathrm{s}$-metolachlor $\left(1,665 \mathrm{~g} \mathrm{ha}^{-1}+1,035 \mathrm{~g} \mathrm{ha}^{-1}\right)$ and s-metolachlor $\left(1,440 \mathrm{~g} \mathrm{ha}^{-1}\right)$ negatively affected the plant stand of the BRS 509, BRS 506 and BRS 511 cultivars. BRS 509 was the least affected by s-metolachlor $\left(1,440 \mathrm{~g} \mathrm{ha}^{-1}\right)$, having its final stand reduced approximately $30 \%$, when subjected to the application of this herbicide.

The reduction in plant stand directly affects crop yield due to the small tillering capacity of the cultivars, in addition to being more susceptible to the weed interference caused by less shading of the interrow (Fernandes et al. 2014). Regarding the comparison of plant stand between cultivars, the data showed similarities with plant height and stem diameter (Table 4), i.e., there were differences between the treatments applied on the cultivars.

The total green mass weight (TGMW) is one of the main yield components of sweet sorghum, as it is directly correlated to the volume of juice produced (Pereira Filho et al. 2013). The TGMW of the cultivars was negatively affected by the application of herbicides, except for BRS 511, where atrazine $\left(1,500 \mathrm{~g} \mathrm{ha}^{-1}\right)$ resulted in a fresh biomass similar to the weeded control (Table 5). For the other cultivars (BRS 506 and BRS 509), all herbicides resulted in lower TGMW, when compared to the weeded control. Comparing cultivars within each herbicide application, it was observed that the use of atrazine + s-metolachlor $\left(1,665 \mathrm{~g} \mathrm{ha}^{-1}+1,035 \mathrm{~g} \mathrm{ha}^{-1}\right)$, atrazine $\left(1,500 \mathrm{~g} \mathrm{ha}^{-1}\right)$ and flumioxazin $\left(50 \mathrm{~g} \mathrm{ha}^{-1}\right)$ promoted greater losses of TGMW for BRS 506 and minor damage to the other two sorghum cultivars.

Table 5. Number of plants per meter and total green mass weight in the sweet sorghum crop due to the application of herbicides.

\begin{tabular}{|c|c|c|c|c|c|}
\hline \multirow{3}{*}{ Treatment } & \multirow{3}{*}{ Dose $\left(\mathrm{g} \mathrm{ha}^{-1}\right)$} & \multirow{3}{*}{ Application time } & \multicolumn{3}{|c|}{ Cultivars } \\
\hline & & & BRS 509 & BRS 506 & BRS 511 \\
\hline & & & \multicolumn{3}{|c|}{ Number of plants (per meter) } \\
\hline Atrazine & 1,500 & Pre $^{1}$ & $13.00 \mathrm{aA}^{3}$ & $8.33 \mathrm{abB}$ & $10.00 \mathrm{abB}$ \\
\hline Atrazine + s-metolachlor & $1,665+1,035$ & Pre & $8.67 \mathrm{cA}$ & $5.00 \mathrm{cB}$ & $6.67 \mathrm{cdAB}$ \\
\hline Flumioxazin & 50 & Pre & $11.33 \mathrm{abcA}$ & $9.00 \mathrm{aB}$ & $9.33 \mathrm{bcAB}$ \\
\hline S-metolachlor & 1,440 & Pre & $8.33 \mathrm{cA}$ & $5.33 \mathrm{bcB}$ & $5.00 \mathrm{~dB}$ \\
\hline Tembotrione & 100.8 & Post & $0.00 \mathrm{dA}$ & $0.00 \mathrm{dA}$ & $0.00 \mathrm{eA}$ \\
\hline Atrazine + s-metolachlor + tembotrione & $1,665+1,035+100.8$ & Pre + post $^{2}$ & $0.00 \mathrm{dA}$ & $0.00 \mathrm{dA}$ & $0.00 \mathrm{eA}$ \\
\hline Atrazine + tembotrione & $1,500+100.8$ & Pre + post & $0.00 \mathrm{dA}$ & $0.00 \mathrm{dA}$ & $0.00 \mathrm{eA}$ \\
\hline Flumioxazin + tembotrione & $50+100.8$ & Pre + post & $0.00 \mathrm{dA}$ & $0.00 \mathrm{dA}$ & $0.00 \mathrm{eA}$ \\
\hline Unweeded control & - & - & $12.50 \mathrm{abA}$ & $9.33 \mathrm{aB}$ & $13.00 \mathrm{aA}$ \\
\hline Weeded control & - & - & $9.67 \mathrm{bcAB}$ & $9.00 \mathrm{aB}$ & $11.33 \mathrm{abA}$ \\
\hline General average & - & - & \multicolumn{3}{|c|}{5.49} \\
\hline CV $(\%)$ & - & - & \multicolumn{3}{|c|}{20.67} \\
\hline Treatment & Dose $\left(\mathrm{g} \mathrm{ha}^{-1}\right)$ & Application time & \multicolumn{3}{|c|}{ Total green mass weight $\left(\mathrm{kg} \mathrm{ha}^{-1}\right)$} \\
\hline Atrazine & 1,500 & Pre $^{1}$ & $76,889 \mathrm{bB}^{3}$ & $40,444 \mathrm{cA}$ & $81,807 \mathrm{aA}$ \\
\hline Atrazine + s-metolachlor & $1,665+1,035$ & Pre & $61,444 \mathrm{cA}$ & $23,807 \mathrm{~dB}$ & $65,556 \mathrm{bA}$ \\
\hline Flumioxazin & 50 & Pre & $76,333 \mathrm{bA}$ & $37,889 \mathrm{cC}$ & $54,422 \mathrm{cB}$ \\
\hline S-metolachlor & 1,440 & Pre & $50,956 \mathrm{dA}$ & 46,326 bcA & $46,778 \mathrm{cA}$ \\
\hline Tembotrione & 100.8 & Post & $0 \mathrm{eA}$ & $0 \mathrm{eA}$ & $0 \mathrm{dA}$ \\
\hline Atrazine + s-metolachlor + tembotrione & $1,665+1,035+100.8$ & Pre + post $^{2}$ & $0 \mathrm{eA}$ & $0 \mathrm{eA}$ & $0 \mathrm{dA}$ \\
\hline Atrazine + tembotrione & $1,500+100.8$ & Pre + post & $0 \mathrm{eA}$ & $0 \mathrm{eA}$ & $0 \mathrm{dA}$ \\
\hline Flumioxazin + tembotrione & $50+100.8$ & Pre + post & $0 \mathrm{eA}$ & $0 \mathrm{eA}$ & $0 \mathrm{dA}$ \\
\hline Unweeded control & - & - & $48,622 \mathrm{~dB}$ & $52,222 \mathrm{bB}$ & $63,933 \mathrm{bA}$ \\
\hline Weeded control & - & - & $86,415 \mathrm{aA}$ & 84,778 aA & $85,970 \mathrm{aA}$ \\
\hline General average & - & - & & 36,153 & \\
\hline $\mathrm{CV}(\%)$ & - & - & & 8.83 & \\
\hline
\end{tabular}


The loss of income resulting from the application of atrazine $\left(1,500 \mathrm{~g} \mathrm{ha}^{-1}\right)$ and flumioxazin $\left(50 \mathrm{~g} \mathrm{ha}^{-1}\right)$ can be mainly attributed to the inefficiency of these molecules to control the weeds present in the plots. Weeds cause competition with the crop, decreasing yield. For treatments containing s-metolachlor $\left(1,440 \mathrm{~g} \mathrm{ha}^{-1}\right)$, the loss of income is mainly due to the reduction in the final plant stand (Table 5). In addition, this herbicide caused high phytotoxicity to the cultivars and inefficiency in the control of I. indivisa.

Comparing the sweet sorghum cultivars (BRS 509, BRS 506 and BRS 511), it was observed that they did not differ statistically for TGMW by applying the s-metolachlor $\left(1,440 \mathrm{~g} \mathrm{ha}^{-1}\right)$ herbicide (Table 5). It is noteworthy that the weed management of I. indivisa, $D$. ciliares and $U$. plantaginea that infest the sweet sorghum crop is important because the weeded control produced an average of $85.72 \mathrm{t} \mathrm{ha}^{-1}$, for the three cultivars, representing 56.05\% more TGMW than the unweeded control. When comparing the most selective herbicide (atrazine - 1,500 $\mathrm{g} \mathrm{ha}^{-1}$ ) for the three cultivars, it was observed an average increase of $11.47 \mathrm{tha}^{-1}(20.89 \%)$ over the absence of control (unweeded control). For the other herbicides, a similar behavior for plant height, stalk diameter and number of plants per meter was observed.

In order to provide more information about the susceptibility of the sorghum crop to herbicides, new tests in different soil and climatic conditions, involving new cultivars, herbicides and management strategies, are required, in order to prospect the selectivity and effectiveness of molecules to the crop. In the present study, it was observed that flumioxazin $\left(50 \mathrm{~g} \mathrm{ha}^{-1}\right)$ has a potential use in sorghum to control broadleaf weeds, showing low phytotoxicity symptoms to the crop. Our results also indicate that tembotrione $\left(100.8 \mathrm{~g} \mathrm{ha}^{-1}\right)$ should not be recommended, as it caused the death of plants from the three cultivars. Differences in tolerance to atrazine among cultivars $\left(1,500 \mathrm{~g} \mathrm{ha}^{-1}\right)$ were also observed.

\section{CONCLUSIONS}

1. Tembotrione (100.8 $\left.\mathrm{g} \mathrm{ha}^{-1}\right)$, flumioxazin + tembotrione $\left(50 \mathrm{~g} \mathrm{ha}^{-1}+100.8 \mathrm{~g} \mathrm{ha}^{-1}\right)$, atrazine + s-metolachlor + tembotrione $\left(1,665 \mathrm{~g} \mathrm{ha}^{-1}+\right.$ $\left.1,035 \mathrm{gha}^{-1}+100.8 \mathrm{~g} \mathrm{ha}^{-1}\right)$ and atrazine + tembotrione $\left(1,500 \mathrm{~g} \mathrm{ha}^{-1}+100.8 \mathrm{~g} \mathrm{ha}^{-1}\right)$ causes high phytotoxicity to sweet sorghum and, therefore, cannot be recommended to the BRS 509, BRS 506 and BRS 511 cultivars.

2. S-metolachlor $\left(1,440 \mathrm{~g} \mathrm{ha}^{-1}\right)$ showed high phytotoxicity to the BRS 506 and BRS 511 cultivars and lower injuries to BRS 509.

3. Tembotrione $\left(100.8 \mathrm{~g} \mathrm{ha}^{-1}\right)$, tembotrione + flumioxazin $\left(50 \mathrm{~g} \mathrm{ha}^{-1}+100.8 \mathrm{gha}^{-1}\right)$, s-metolachlor + atrazine + tembotrione $\left(1,665 \mathrm{~g} \mathrm{ha}^{-1}+1,035 \mathrm{~g} \mathrm{ha}^{-1}+\right.$ $\left.100.8 \mathrm{~g} \mathrm{ha}^{-1}\right)$ and atrazine + tembotrione $\left(1,500 \mathrm{gha}^{-1}+\right.$ $100.8 \mathrm{~g} \mathrm{ha}^{-1}$ ) control Ipomoea indivisa, Digitaria ciliaris and Urochloa plantaginea.

4. Atrazine $\left(1,500 \mathrm{~g} \mathrm{ha}^{-1}\right)$ can be recommended for controlling Ipomoea indivisa in sorghum.

5. Atrazine $\left(1,500 \mathrm{~g} \mathrm{ha}^{-1}\right)$, in general, shows higher selectivity to yield componentes, for the BRS 509 and BRS 506 sorghum cultivars.

\section{REFERENCES}

ARMEL, G. R. et al. Mesotrione plus atrazine mixtures for control PF Canada thistle (Cirsium arvense). Weed Science, v. 53, n. 2, p. 202-211, 2005.

ASSOCIAÇÃo BRASILEIRA DO COMÉRCIO DE SEMENTES E MUDAS (ABCSM). Instrução Normativa Conjunta n. 1, de 16 de junho de 2014. 2014. Available at: <http://www.abcsem.com.br/upload/ arquivos/INC_01_2014(1).pdf $>$. Acess on: 05 Mar. 2016.

BRASIL. Instituto Nacional de Meteorologia. Precipitação total, temperatura média mensal $\left({ }^{\circ} \mathrm{C}\right) .2015$. Available at: $<$ http://www.inmet.gov.br>. Acess on: 07 Apr. 2016.

BRASIL. Ministério da Agricultura Pecuária e Abastecimento. Registro nacional de cultivares. 2014. Available at: <http://www.agricultura.gov.br/vegetal $>$. Acess on: 05 Mar. 2016.

BUNTING, J. A. et al. Corn tolerance as affected by the timing of foramsulfuron applications. Weed Technology, v. 18, n. 3, p. 757-762, 2004.

COSTA, N. V. et al. Controle do milho voluntário tolerante ao glyphosate em dois estádios de desenvolvimento. Planta Daninha, v. 32, n. 4, p. 675-682, 2014.

DAN, H. A. et al. Tolerância de sorgo granífero ao herbicida tembotrione. Planta Daninha, v. 28, n. 3, p. 615620, 2010.

FERNANDES, P. G. et al. Influência do espaçamento e da população de plantas de sorgo sacarino em diferentes épocas de semeadura. Ciência Rural, v. 44, n. 6, p. 975981, 2014. 
JORDAN, T. N.; WARREN, G. R. Herbicide combinations and interactions. In: JORDAN, T. N.; WARREN, G. R. Herbicide action course. West Lafayette: Purdue University, 1995. p. 232-234.

MACIEL, C. D. G. et al. Eficácia do herbicida Haloxyfop $\mathrm{R}$ (GR-142) isolado e associado ao 2,4-D no controle de híbridos de milho $\mathrm{RR}^{\circledR}$ voluntário. Revista Brasileira de Herbicidas, v. 12, n. 2, p. 112-123, 2013.

MARTINS, C. C. et al. Seletividade de herbicidas sobre a produtividade e qualidade de sementes de sorgo granífero. Agropecuária Técnica, v. 27, n. 1, p. 37-42, 2006.

PEREIRA FILHO, I. A. et al. Avaliação de cultivares de sorgo sacarino [Sorghum bicolor (L.) Moench] em diferentes densidades de semeadura visando a características importantes para a produção de etanol. Revista Brasileira de Milho e Sorgo, v. 12, n. 2, p. 118127, 2013.

RATNAVATHI, C. V. et al. Study on genotypic variation for ethanol production from sweet sorghum juice. Biomass and Bioenergy, v. 34, n. 7, p. 947-952, 2010.

REDE OFICIAL DE LABORATÓRIOS DE ANÁLISE DE SOLO E DE TECIDO VEGETAL (ROLAS). Manual de adubação e calagem para os Estados do Rio Grande do Sul e Santa Catarina. 10. ed. Porto Alegre: Sociedade Brasileira de Ciência do Solo, 2004.

RODRIGUES, B. N.; ALMEIDA, F. S. Guia de herbicidas. Londrina: UEL, 2011.

SILVA, A. F. et al. Manejo de plantas daninhas. In: BORÉM, A. et al. (Eds.). Sorgo: do plantio à colheita. Viçosa: UFV, 2014a.

SILVA, C. et al. Interferência de plantas daninhas na cultura do sorgo sacarino. Bragantia, v. 73, n. 4, p. 438445, 2014b.

SOCIEDADE BRASILEIRA DA CIÊNCIA DAS PLANTAS DANINHAS (SBCPD). Procedimentos para instalação, avaliação e análise de experimentos com herbicidas. Londrina: SBCPD, 1995.

STRECK, E. V. et al. Solos do Rio Grande do Sul. 2. ed. Porto Alegre: Emater/RS-ASCAR, 2008.

WERLANG, R. C.; SILVA, A. A. Interação de glyphosate com carfentrazone-ethyl. Planta Daninha, v. 20, n. 1, p. 93-102, 2002.

ZAGONEL, J. et al. Controle pós-emergente de plantas daninhas em cenoura. Horticultura Brasileira, v. 17, n. 1, p. 69-71, 1999. 